\title{
Initial beaked hazel growth responses following protection from ungulate browsing
}

\author{
JODY N. BEST ${ }^{1}$, EDWARD W. BORK ${ }^{2}$, AND NORMAND L. COOL
}

Authors are former Graduate Research Assistant and Associate Professor, Department of Agricultural, Food, and Nutritional Science, $410 E$, AgFor Centre, University of Alberta, Edmonton, Alberta, Canada T6G 2P5; Senior Park Biologist, Elk Island National Park, Box 7, Site 4, R.R. 1, Fort Saskatchewan, Alberta, Canada T8L 2 N7.

${ }^{1}$ Present address is Alberta Sustainable Resource Development, Box 3092, High Prairie, Alberta, T0G 1E0. ${ }^{2}$ Author for correspondence.

\begin{abstract}
Beaked hazel (Corylus cornuta Marsh) dominates the understory of many Boreal Mixedwood forests in central Alberta including those in Elk Island National Park, where this species demonstrates a high tolerance to browsing. This research quantified changes in beaked hazel stem morphology (total twig length and number) and leaf and twig biomass of current annual growth, both inside and outside 4 newly established exclosures during the growing seasons of 1999 and 2000 . At 2 sites, leaf and twig current annual growth of beaked hazel shrubs recently protected from herbivory increased significantly $(P<0.05)$ by 85 to $114 \%$ relative to that of browsed shrubs. At another site, the removal of browsing changed the morphology of beaked hazel shrub growth $(\mathrm{P}<\mathbf{0 . 0 5})$, with protected shrubs producing $26 \%$ more twigs that were shorter in aggregate length by $27 \%$. The final site exhibited no significant $(P>0.05)$ changes in current annual growth at the individual shrub stem level, potentially due to intense intra-specific competition. These results indicate that at several locations in the Park, the recent history of intense browsing appears to be limiting the annual growth of beaked hazel, including browse production. Despite the general increase in growth of individual beaked hazel stems, however, no changes in production were evident at the community level $(P>0.05)$ with the removal of browsing after 2 years. Protection from browsing did increase average beaked hazel height by $40 \%$ over the same period.
\end{abstract}

Key Words: boreal forest, browsing release, Corylus cornuta, current annual growth, exclosures, shrub morphology

Beaked hazel (Corylus cornuta Marsh.) is a common understory shrub within the Lower Boreal Mixedwood (LBM) forests of western Canada, occurring mainly on moderately well-drained, moist sites (Willoughby 2000). Beaked hazel is a prolific shrub capable of producing vegetative clones via underground stems that produce new roots and aerial stems along their length

This research was funded by Elk Island National Park, the University of Alberta, the Friends of Elk Island Society, and the Alberta Sports, Recreation, Parks, and Wildlife Foundation, along with Norwest Labs and the Throlson American Bison Foundation. The authors would like to thank numerous field assistants who helped with various components of data collection, and the staff at EINP who provided logistical support, along with Peter Blenis, and Laki Goonewardene who aided with data analysis. We also thank Bob Hudson, Ellen Macdonald, Evelyn Merrill, Walter Willms, and 2 anonymous reviewers, who provided helpful comments on earlier versions of the manuscript.

Manuscript accepted 9 Oct. 02.

\section{Resumen}

El "Beaked hazel" (Corylus cornuta Marsh) domina el estrato arbustivo de muchos bosques Boreales Mixtos de la región central de Alberta, incluyendo los de Elk Island National Park, donde esta especie demuestra una alta tolerancia al ramoneo. Esta investigación cuantifico los cambios en la morfología de tallos (longitud total y número de ramas ) y la biomasa de hojas y ramas del crecimiento anual actual del "Beaked hazel", tanto dentro como fuera de 4 exclusiones recientemente establecidas durante las estaciones de crecimiento de 1999 y 2000. En 2 sitios, el crecimiento anual actual de hojas y tallos de arbustos de "Beaked hazel" recién protegidos de la herviboría se incremento significativamente $(P<0.05)$ de 85 a 114\% en comparación con los arbustos ramoneados. En otro sitio, la remoción del ramoneo cambio la morfología de crecimiento del "Beaked hazel" $(\mathbf{P}<$ $0.05)$, los arbustos protegidos produjeron $26 \%$ más ramas que fueron $27 \%$ mas cortas en la longitud agregada. El sitio final no mostro cambios significativos $(P>0.05)$ en el crecimiento anual actual al nivel individual de tallo del arbusto, debido potencialmente a la intensa competencia intraespecifica. Esto resultados indican, que en varias localidades del Parque, la historia reciente de ramoneo intenso parece ser limitante del crecimiento anual del "Beaked hazel", incluyendo la producción de forraje para ramoneo. Sin embargo, a pesar del incremento general de crecimiento de los tallos individuales del "Beaked hazel", a nivel de comunidad, no hubo cambios evidentes en la producción ( $\mathbf{P}>$ 0.05) 2 años después de la remoción del ramoneo. En el mismo periodo de tiempo la protección contra el ramoneo incremento en $40 \%$ la altura promedio del "Beaked hazel".

(Tappeiner and John 1973). Clones are typically less than $2 \mathrm{~m}$ in diameter (Tappeiner 1971). As stands of beaked hazel age, the total phytomass and proportion of young stems in the population increases. However, beaked hazel density eventually declines as the tree overstory and shading increases (Kurmis and Sucoff 1989). Beaked hazel can influence forest ecology, with high densities inhibiting tree reproduction and reducing the abundance of more palatable browse species, as well as changing light intensity and the composition of litter in the understory (Tappeiner 1979, 1971).

Elk Island National Park (EINP) is located in east-central Alberta and has an understory dominated by dense stands of beaked hazel (Hardy Associates Ltd. 1986). Despite the abundance of beaked hazel and its role in providing the majority of 
available browse to native ungulates (Blyth et al. 1994), little information exists on the intra-specific response of this shrub to current levels of herbivory within the Park. Studies on other shrub species have found browsing may lead to reduced foraging opportunities for wildlife (e.g. Wambolt and Sherwood 1999, Bork et al. 1997a). Given that previous research has shown stem mortality may eventually lead to an increase in beaked hazel density (Tappeiner 1979), heavy browsing of this species may lead to unexpected increases in browse production.

This study assessed the effect of browsing on beaked hazel shrubs within EINP. To accomplish this, we employed the approach of Yokoyama and Shibata (1998) and quantified relative changes in the morphology and biomass of current annual growth within individual shrub stems for 2 successive years following the cessation of browsing. We hypothesized that if current levels of browsing suppress beaked hazel growth, stems recently protected from browsing would have greater current annual growth. Conversely, should intensive browsing facilitate beaked hazel current annual growth, individual stem growth would be lower in protected shrubs over the same period. A secondary objective was to compare beaked hazel growth at the population (i.e. per unit area) level with that at the individual stem (i.e. ramet) level, as previous growth responses have been found to differ depending on the biological scale of investigation (Tolvanen et al. 1992, Wambolt et al. 1998).

\section{Methods}

\section{Study Site}

Elk Island National Park is a $194 \mathrm{~km}^{2}$ area situated $37 \mathrm{~km}$ east of Edmonton, Alberta $\left(53^{\circ} 37^{\prime} \mathrm{N}, 112^{\circ} 58^{\prime} \mathrm{W}\right)$ within the Beaver Hills-Cooking Lake Moraine. The Park is elevated up to $60 \mathrm{~m}$ above the surrounding plains (710 to $760 \mathrm{~m} \mathrm{ASL}$ ), and is composed of knob and kettle topography, with slopes up to $20 \%$. Upland soils are mostly well-drained Orthic Gray Luvisols under forest (Crown 1977), while Dark Gray Luvisols occupy open areas. Soil textures vary from loam to loamy sand.

Located in the cool continental climatic region, the Park receives about $450 \mathrm{~mm}$ of precipitation annually, with $75 \%$ falling as summer rain (Environment Canada 1993). Temperatures vary from $-40^{\circ} \mathrm{C}$ in winter to $32^{\circ} \mathrm{C}$ in summer.

Uplands are dominated by aspen (Populus tremuloides Michx.) forests, which cover approximately $80 \%$ of the Park. The understory consists of a variety of herbs and shrubs, of which beaked hazel and marsh reedgrass (Calamagrostis canadensis (Michx.) Beauv.) are the most abundant (Bork et al. 1997a). These stands produce up to $1,700 \mathrm{~kg} \mathrm{ha}^{-1}$ of total new growth in the understory, of which 47 to $68 \%$ is browse.
Elk Island is the only fenced national park in Canada and lacks major predators such as wolves. These conditions have resulted in high ungulate populations and intense use of vegetation. In 1999 , aerial ungulate surveys estimated there were 3,493 large ungulates within the Park, including 340 moose, 1,870 elk, 1,043 bison, and 210 deer (Parks Canada 1999). Based on the year-long herbivore regime within the Park, these numbers are equivalent to an annual stocking rate of approximately 2 AUMs ha $^{-1}$ (Best 2001).

Prescribed fire and herbivory are 2 of the main factors affecting vegetation within the Park (Parks Canada 1999, Bork et al. 1997a). Specifically, intense year-long herbivory over the past 80 years has reduced the abundance of preferred browse species such as aspen, chokecherry (Prunus virginiana L.), saskatoon (Amelanchier alnifolia Nutt.), as well as red-osier dogwood (Cornus stolonifera Michx.), and reduced the remaining shrubs to a hedged growth form (Parks Canada 1999, Bork et al. 1997a, 1997b). Aspen regeneration has also declined (Bork et al. 1997b). Although beaked hazel provides up to $75 \%$ of all browsed twigs, this species is the most abundant understory shrub (34\% of all stems) and has been reported to be increasing in proportion to other understory species (Blyth et al. 1994). Specific utilization data for beaked hazel within the Park between 1991 and 1994 indicated annual winter twig use ranged from 40 to $55 \%$ (Blyth et al. 1994).

\section{Experimental Design}

In October 1998, 4 ungulate-proof exclosures, each 20 by $50 \mathrm{~m}$ in dimension and $2.2 \mathrm{~m}$ high, were constructed throughout the Park. Each exclosure was positioned locally to include a forest community, the understory of which consisted of beaked hazel along with various other shrubs. Plot pairs therefore consisted of an aspen-beaked hazel community divided by the exclosure fence, initially resulting in 2 areas of similar plant species composition and structure, as well as site characteristics (Table 1). Communities outside the exclosure were exposed to year-long, native ungulate herbivory, while enclosed communities were protected from browsing. Given that most browsing occurs during winter when alternative herbage is largely unavailable (Danell et al. 1994) and no evidence of summer browsing was apparent on the new growth of protected beaked hazel stems at the time of exclosure establishment (i.e. October), plants sampled the following summer were considered rested for 1 growing season.

\section{Vegetation Sampling}

Within each plant community inside and outside each exclosure, shrubs were sampled along a $15 \mathrm{~m}$ transect. At each of 20 sample points, 2 beaked hazel stems were systematically selected and tagged $0.75 \mathrm{~m}$ apart ( $\mathrm{n}=40$ shrubs per community).

Table 1. Summary site descriptions for protected and unprotected forest communities at each of the 4 locations investigated.

\begin{tabular}{|c|c|c|c|c|c|c|c|c|}
\hline Exclosure/ Site & Treatment & Slope & Aspect & 1999 Rainfall & 2000 Rainfall & Soil Texture $^{1}$ & Tree Density & Tree Cover \\
\hline \multirow{3}{*}{ Boreal } & & $(\%)$ & & $(\mathrm{mm})$ & $(\mathrm{mm})$ & & $\left(\right.$ stem.ha $\left.^{-1}\right)$ & $(\%)$ \\
\hline & Protected & 16 & $\mathrm{NE}$ & 141 & 178 & $\mathrm{~L}$ to $\mathrm{SL}$ & 1,400 & 76 \\
\hline & Browsed & 19 & $\mathrm{~N}$ & 141 & 178 & SL & 1,350 & 82 \\
\hline \multirow[t]{2}{*}{ Astotin } & Protected & 13 & SW & 330 & 264 & $\mathbf{L}$ & 275 & 7 \\
\hline & Browsed & 13 & $\mathrm{~W}$ & 330 & 264 & $\mathbf{L}$ & 100 & 11 \\
\hline \multirow[t]{2}{*}{ Shirley } & Protected & 27 & NW & 172 & 175 & $\mathrm{C}$ & 925 & 55 \\
\hline & Browsed & 20 & NW & 172 & 175 & $\mathrm{CL}$ & 500 & 30 \\
\hline \multirow[t]{2}{*}{ Tawayik } & Protected & 0 & $\mathrm{n} / \mathrm{a}$ & 193 & 227 & L & 1,975 & 66 \\
\hline & Browsed & 0 & $\mathrm{n} / \mathrm{a}$ & 193 & 227 & $\mathrm{~L}$ to $\mathrm{SL}$ & 1,950 & 82 \\
\hline
\end{tabular}

$\mathrm{T} \mathrm{L}=$ loam, $\mathrm{SL}=$ sandy loam, $\mathrm{C}=$ clay, $\mathrm{CL}=$ clay loam. 
Individual stems were defined as those free-standing at the soil surface. During August of 1999, one shrub stem at every point was sampled, with 20 shrubs harvested inside and 20 outside at each of the 4 exclosures $(n=160)$. The remaining 20 shrubs were sampled in each community during August 2000. Sampling in the first year was assumed to have a negligible effect on neighboring shrubs sampled in the second year, particularly given that sampling removed current annual growth only and affected a maximum of $0.3 \%$ of shrubs at any one location.

Parameters measured on each stem included the number of current annual growth (CAG) twigs per shrub and their total length, together with twig and leaf biomass. All new growth was clipped, sorted to twigs and leaves, dried at $50^{\circ} \mathrm{C}$ for 48 hours, and weighed. The samples were later pooled to the plant community level (i.e. the 20 shrubs) and analysed for crude protein $(\mathrm{CP})$ and acid detergent fibre (ADF). Crude protein analysis was done using a Nitrogen Determinator (LECO Corporation, St. Joseph, Mich., USA) while ADF was measured using the filter bag technique (ANKOM Company 1993).

\section{Community Attributes}

In the second year, 2 additional $15 \mathrm{~m}$ transects were located in each of the 8 plant communities to measure overstory tree canopy cover and density, total shrub density and maximum shrub height, as well as beaked hazel cover, density, and current annual growth (CAG) per unit area at peak growth during August of 2000. Tree canopy cover was estimated using the line intercept method (Bonham 1989), while tree density was determined in a 20 by $20 \mathrm{~m}$ area overlying the transects. Beaked hazel cover (Daubenmire 1959) and density, along with total shrub density and maximum shrub height, were sampled at $2 \mathrm{~m}$ intervals along both transects within $1 \mathrm{~m}^{2}$ quadrats $(\mathrm{n}=16)$. Beaked hazel total leaf and twig CAG (per unit area) within the plant community was measured within $2,0.25 \mathrm{~m}^{2}$ quadrats harvested at systematic locations along each transect. All samples were oven-dried and weighed, with data from the 4 individual quadrats averaged to provide a value for the plant community.

Within each plant community, data were also collected on slope gradient, aspect, and soils, as well as growing season precipitation (May to August) within each year of the study (Table 1). Although winter precipitation is important for determining moisture recharge in boreal systems
(Bork et al. 2001) and for regulating browsing intensity by herbivores during winter, local snow depth data for the exclosures were not available for the study period. Data from a central weather station within the Park, however, indicated winter (i.e. September through April) snowfall accumulations during 1998-99 and 1999-2000 were 111 and $105 \mathrm{~cm}$, respectively, very similar to the 20 -year mean for the area $(107 \mathrm{~cm})$ (Environment Canada, unpublished data). Four soil cores $(0-15 \mathrm{~cm})$ were randomly collected at each plant community in October 2000, bulked, and analysed for soil texture using the hydrometer method described by McKeague (1978).

\section{Data Analysis}

All shrub data were checked for normality and homogeneity of variances using Shapiro-Wilkes and Levenes statistics, respectively (SAS Institute Inc. 1991). Beaked hazel CAG at the plant community level was transformed using a log transformation, as were individual beaked hazel stem CAG twig counts, total twig length, and leaf and twig CAG.

In this investigation, plant communities were considered the primary experimental unit at each exclosure with sites treated as blocks because individual shrubs represented sub-samples, and thus, pseudoreplication (Hurlburt 1984). As a result, the interaction of site by herbivory was used as the primary error term for all main effects. Where significant interactions between herbivory and site were found on individual beaked hazel stem parameters, variation among sub-samples (i.e. individual stems) was used as the error term in a final step to more fully assess the nature of the interaction. Additionally, year was incorporated into the model as a split-plot to test for temporal differences in beaked hazel shrub recovery during the first and second years following protection from herbivory.

Total shrub density and maximum shrub height for each community were analysed using ANOVA procedures for a randomized complete block design (Steel et al. 1997), with the interaction of site and protection from herbivory as the error term. Beaked hazel cover, density, and production per unit area were analyzed using ANCOVA, where non-hazel shrub density was used as a covariate. In no case was the covariate significant $(P>0.10)$.

Individual beaked hazel stem current annual growth (CAG) parameters were analyzed similarly using ANOVA (leaf and twig CAG, as well as browse quality).
Significant interaction effects were assessed in more detail using the variation provided by sub-sampled shrubs within each plant community. ANCOVA was used to assess morphological changes in shrub growth in order to account for uneven twig numbers and/or length among shrubs and isolate treatment effects. Twig numbers per shrub were adjusted for twig length, and vice versa in the ANCOVA, with significant covariate effects found in all cases $(P<0.0001)$. Incorporation of the covariate, however, did not alter the significance of any treatment effects. Posthoc mean comparisons were conducted on all significant variables $(\mathrm{P}<0.05)$ using Tukey's test, emphasizing those between protected and browsed areas.

\section{Results and Discussion}

\section{Beaked Hazel Population Responses}

The cover of beaked hazel varied among the exclosure sites $(\mathrm{P}<0.05)$, but was similar between browsed and protected treatments in 2000 (Table 2). Among the 4 sites, Astotin had the greatest beaked hazel population, followed by the Shirley and Boreal sites, with Tawayik having relatively less. Although the greater abundance of beaked hazel at Astotin may be the result of increased summer rainfall during the 2 years of this study, a relatively open tree canopy may also account for this trend (Table 1). Open canopies are conducive to maintaining high beaked hazel densities (Kurmis and Sucoff 1989, Buckman 1964).

At least 1 other site (Tawayik) had a similar precipitation level (Table 1), but markedly less beaked hazel (Table 2). Unlike Astotin, the Tawayik site had a well-developed, relatively closed forest canopy (Table 1), indicating that light rather than moisture may regulate beaked hazel densities within the communities investigated. Regardless of the cause, the variation in density of beaked hazel among the 4 locations is important ecologically as it may influence other plants through inter-specific competition (Lauer and Glover 1999), as well as its own population through strong intra-specific competition, particularly at Astotin (Table 2).

The lone significant $(\mathrm{P}<0.01)$ difference between browsed and protected treatments observed at the population level was an increase of $40 \%$ in the average maximum shrub height within the exclosures following the removal of herbivory (Table 2). The increase in shrub height might be expected as previous studies 
Table 2. Effects of site (i.e. exclosure location) and protection from herbivory on mean beaked hazel population and plant community characteristics in $\mathbf{2 0 0 0}$.

\begin{tabular}{|c|c|c|c|c|c|c|}
\hline Factor & $\mathrm{df}$ & $\begin{array}{c}\text { Beaked } \\
\text { Hazel Cover }\end{array}$ & $\begin{array}{l}\text { Beaked Hazel } \\
\text { Density }^{1}\end{array}$ & $\begin{array}{l}\text { Beaked Hazel } \\
\mathrm{CAG}^{1,2}\end{array}$ & $\begin{array}{l}\text { Maximum } \\
\text { Shrub Height }\end{array}$ & $\begin{array}{c}\text { Total Shrub } \\
\text { Density }\end{array}$ \\
\hline Covariate & 1 & $\begin{array}{c}(\%) \\
P=0.34\end{array}$ & $\begin{array}{c}\left(\text { stems.m }{ }^{-2}\right) \\
P=0.65\end{array}$ & $\begin{array}{l}\left.\text { (kg.ha }^{-1}\right) \\
P=0.92\end{array}$ & $(\mathrm{~cm})$ & $\left(\right.$ stems m$\left.^{-2}\right)$ \\
\hline Site & 3 & $\mathbf{P}<\mathbf{0 . 0 5}$ & $\mathrm{P}=0.18$ & $P=0.26$ & $\mathrm{P}<\mathbf{0 . 0 5}$ & $P=0.07$ \\
\hline $\begin{array}{l}\text { Astotin } \\
\text { Boreal }\end{array}$ & & $\begin{array}{l}80.4 \mathrm{a}^{3} \\
31.7 \mathrm{ab}\end{array}$ & $\begin{array}{l}31.0 \\
8.0\end{array}$ & $\begin{array}{l}1776 \\
442\end{array}$ & $\begin{array}{l}166.9 \mathrm{a} \\
111.7 \mathrm{~b}\end{array}$ & $\begin{array}{l}40.8 \\
20.2\end{array}$ \\
\hline Shirley & & $38.8 \mathrm{ab}$ & 14.4 & 636 & $128.4 \mathrm{ab}$ & 23.0 \\
\hline Tawayik & & $3.8 \mathrm{~b}$ & 1.2 & 260 & $109.3 \mathrm{~b}$ & 12.7 \\
\hline Herbivory & 1 & $P=0.26$ & $P=0.53$ & $P=0.69$ & $P<0.01$ & $P=0.67$ \\
\hline Browsed & & 41.2 & 12.3 & 822 & $108 \mathrm{a}$ & 23.1 \\
\hline Protected & & 36.2 & 15.0 & 735 & $150 \mathrm{~b}$ & 25.2 \\
\hline SE & & 4.6 & 4.3 & 12 & 4.1 & 3.2 \\
\hline
\end{tabular}

Data analyzed using ANCOVA with non-hazel shrub density as a covariate.

${ }^{2}$ Current annual growth data transformed $(\log )$ prior to analysis. Original means presented for clarity.

${ }^{3}$ Within a factor, column means with different letters differ significantly $(\mathrm{P}<0.05)$

${ }^{4}$ Error term for Site and Herbivory.

have implicated herbivory within the Park as a cause of reduced structure in the understory (Bork et al. 1997b).

\section{Individual Beaked Hazel Stem Growth}

Initial analysis indicated there were significant $(\mathrm{P}<0.001)$ site by herbivory interaction effects for all beaked hazel parameters assessed (Table 3). As a result, individual sites were further analysed separately using the variation among subsampled stems. This process was undertaken to provide a more detailed understanding of beaked hazel shrub responses to the presence or removal of herbivory. We also recognize, however, that although the paired (browsed and protected) plant communities were initially established on similar ecosites, the lack of complete independence among individual shrub stems within each community constitute pseudoreplication, and thus, inferences within each site must be tempered accordingly.

Examination of the individual beaked hazel growth responses among sites indicated that shrubs protected from browsing at both Boreal and Tawayik increased ( $\mathrm{p}<$ 0.05 ) their leaf and twig growth relative to those outside the exclosure, ranging from 85 to $114 \%$ (Table 4). At Tawayik, this increase could be attributed, at least in part, to a significant increase $(P<0.05)$ in the length of new twig growth rather than the number of new twigs produced (Table 4).

Although year significantly $(\mathrm{P}<0.001)$ affected both leaf current annual growth (CAG) and the number of twigs produced per shrub stem (Table 3), few interactions were evident between year and herbivory. Shrub growth was generally greater in 2000 than 1999, as leaf CAG increased

Table 3. Significance values of the effects of site (i.e. exclosure location), protection from herbivory, and their interaction, on individual hazel shrub stem CAG characteristics in 1999 and 2000.

\begin{tabular}{|c|c|c|c|c|c|}
\hline Factor & $\mathrm{df}$ & Leaf $\mathrm{CAG}^{1}$ & Twig $\mathrm{CAG}^{1}$ & $\begin{array}{l}\text { Total Twig Length } \\
\text { per Shrub }^{1,2}\end{array}$ & $\begin{array}{c}\text { Number of } \\
\text { Twigs per Shrub }\end{array}$ \\
\hline Covariate $^{3}$ & 1 & & & $P<0.0001$ & $P<0.0001$ \\
\hline Site & 3 & $P=0.51$ & $P=0.21$ & $P=0.20$ & $P=0.58$ \\
\hline Herbivory & 1 & $P=0.28$ & $P=0.44$ & $P=0.95$ & $P=0.39$ \\
\hline Site $x$ Herbivory ${ }^{3}$ & 3 & $P<0.001$ & $P<0.0001$ & $P<0.0001$ & $P<0.001$ \\
\hline Error 1 & 152 & & & & \\
\hline Year & 1 & $\mathbf{P}<0.001$ & $P=0.17$ & $P=0.20$ & $P<0.0001$ \\
\hline Site $\mathrm{x}$ Year & 3 & $P=0.10$ & $P=0.18$ & $P=0.20$ & $P=0.86$ \\
\hline Herbivory x Year & 1 & $P=0.65$ & $P=0.31$ & $P=0.66$ & $P=0.57$ \\
\hline Site $\mathrm{x}$ Herbivory $\mathrm{x}$ Year $^{4}$ & 3 & $P=0.16$ & $\mathbf{P}<0.05$ & $P=0.31$ & $\mathrm{P}=0.92$ \\
\hline Error 2 & 152 & & & & \\
\hline
\end{tabular}

Data transformed prior to analysis using a log transformation.

${ }^{2}$ Data analyzed using ANCOVA, with twig numbers per shrub adjusted for twig length, and twig length adjusted for twig numbers.

${ }^{3}$ Error term for Site and Herbivory effects.

${ }^{4}$ Error term for Year and its interactions. from 4.92 g.stem ${ }^{-1}$ in 1999 to 5.69 g.stem ${ }^{-1}$ in 2000. Similarly, the mean number of twigs increased from 7.0 twigs.stem $^{-1}$ to 9.3 over this same period. The increase over the 2 years may be due to more favorable growing conditions for beaked hazel, as well as the increases in beaked hazel growth described earlier within protected exclosures.

Twig CAG was also affected by a significant $(\mathrm{P}<0.05)$ interaction between site, herbivory, and year (Table 3 ). Further examination of these results indicated this interaction was caused by variation in the year during which differences in twig growth were evident among sites. For example, at the Boreal exclosure the increase in twig growth within protected beaked hazel shrubs was evident in 1999, immediately following protection from herbivory. In contrast, newly protected shrubs at Tawayik did not generate an increase in twig growth until the second year. The delayed increase in CAG within protected beaked hazel shrubs at the latter site may be indicative of a more intense browsing history prior to exclosure establishment, which would have weakened shrubs by reducing photosynthetic capacity, plant carbohydrates and plant vigour (Briske and Richards 1995).

Beaked hazel shrubs at the Shirley site demonstrated no changes in leaf or twig current annual growth (CAG), but displayed evidence of changes in the morphology of new growth. In particular, protected beaked hazel shrubs produced a significantly $(\mathrm{P}<0.05)$ greater number of new twigs, but which were shorter $(\mathrm{P}<$ 0.05 ) in aggregate length (Table 4$)$. Although these changes did not coincide with significant differences in leaf or twig CAG (Table 4), they may signal future changes in growth as the recovery of protected beaked hazel shrubs progresses at this location.

Protected beaked hazel shrubs at several sites displayed either a non-significant or even weak trend towards reduced growth during the first year of recovery from browsing, before increasing more markedly during the second year (data not shown). We speculate that annual herbivory may stimulate individual beaked hazel growth by forcing stems to regenerate sufficient photosynthetic area to survive. Increases in the root:shoot ratio of plants immediately following defoliation is thought to account for positive responses in the above-ground growth of browsed shrubs (Bryant et al. 1991). With protection during the fall of 1998 , beaked hazel shrubs may have reduced their above-ground growth the fol- 
Table 4. Mean leaf and twig CAG, as well as total length and number of twigs, within individual beaked hazel shrub stems of plant communities protected and exposed to browsing at each of 4 sites in Elk Island National Park.

\begin{tabular}{|c|c|c|c|c|c|}
\hline \multirow[b]{2}{*}{ Site } & \multirow[b]{2}{*}{ Herbivory } & \multicolumn{4}{|c|}{ Parameter } \\
\hline & & Leaf CAG & Twig CAG & Total Twig Length & Twig Number \\
\hline & & $\left(\mathrm{g} \mathrm{DM} \mathrm{stem}^{-1}\right)$ & $\left(\mathrm{g} \mathrm{DM} \mathrm{stem}^{-1}\right)$ & $\left.(\mathrm{cm} \mathrm{stem})^{-1}\right)$ & $\left(\right.$ no stem $\left.{ }^{-1}\right)$ \\
\hline \multirow{3}{*}{ Astotin } & Browsed & $7.47 \mathrm{a}^{1}$ & $2.43 \mathrm{a}$ & $110 \mathrm{a}$ & $5.5 \mathrm{a}$ \\
\hline & Protected & $6.50 \mathrm{a}$ & $2.15 \mathrm{a}$ & $94 \mathrm{a}$ & $6.5 \mathrm{a}$ \\
\hline & $\mathrm{SE}$ & 1.21 & 0.34 & 16 & 1.7 \\
\hline \multicolumn{6}{|l|}{ Boreal } \\
\hline & Browsed & $3.56 \mathrm{a}$ & $1.23 \mathrm{a}$ & $73 \mathrm{a}$ & $7.7 \mathrm{a}$ \\
\hline & Protected & $7.46 \mathrm{~b}$ & $2.27 \mathrm{~b}$ & $72 \mathrm{a}$ & $10.2 \mathrm{a}$ \\
\hline & SE & 1.16 & 0.32 & 15 & 2.1 \\
\hline \multicolumn{6}{|l|}{ Shirley } \\
\hline & Browsed & $3.59 \mathrm{a}$ & $1.10 \mathrm{a}$ & $64 \mathrm{a}$ & $8.6 \mathrm{a}$ \\
\hline & Protected & $3.43 \mathrm{a}$ & $0.78 \mathrm{a}$ & $47 \mathrm{~b}$ & $10.8 \mathrm{~b}$ \\
\hline & $\mathrm{SE}$ & 0.47 & 0.17 & 6 & 1.0 \\
\hline \multicolumn{6}{|l|}{ Tawayik } \\
\hline & Browsed & $3.60 \mathrm{a}$ & $0.81 \mathrm{a}$ & $62 \mathrm{a}$ & $9.0 \mathrm{a}$ \\
\hline & Protected & $6.82 \mathrm{~b}$ & $1.73 \mathrm{~b}$ & $86 \mathrm{~b}$ & $6.8 \mathrm{a}$ \\
\hline & $\mathrm{SE}$ & 0.72 & 0.21 & 9 & 0.9 \\
\hline \multicolumn{6}{|l|}{ All Sites } \\
\hline & Browsed & 4.56 & 1.39 & 77 & 7.7 \\
\hline & Protected & 6.06 & 1.73 & 75 & 8.6 \\
\hline
\end{tabular}

${ }^{\mathrm{T}}$ Within a parameter and column, means with different letters differ significantly at $\mathrm{P}<0.05$ using sub-samples as the experimental error term.

lowing summer because new growth produced the previous growing season remained intact. In turn, this would allow more photosynthates to be allocated to other important biological processes for plant recovery, including root development. As much as $39 \%$ of beaked hazel biomass is below-ground (Tappeiner and John 1973) and plays a key role in determining hazel survival.

The variable response between protected and browsed beaked hazel stems among the 4 sites may be attributable to several factors, including variability in precipitation, overstory cover, historical browsing pressure, or intra-specific competition. For example, high summer rainfall and an open tree canopy at Astotin (Table 1) may allow beaked hazel shrubs to more easily tolerate defoliation, leading to the absence of differences between protected and browsed shrubs at this site (Table 4 ). In addition, although shrubs at Astotin were clearly browsed (as evidenced by a welldefined hedge-line), they were considerably taller than shrubs at other sites (Table 2), which may allow them to restore leaf area more readily. Moreover, the unusually high density of beaked hazel at this site (Table 2) may maximize intra-specific competition. Beaked hazel plants compete very effectively with other shrub species by reducing light at the forest floor (Tappeiner 1979, Tappeiner and John 1973). The results observed here suggest beaked hazel stems may also compete with each other for resources and limit growth at high stand densities, thereby negating any potential growth response following the removal of browsing. Under these circumstances, removal of browsing may lead to stagnation and reduced growth of beaked hazel shrubs within the Astotin exclosure. There was also weak evidence of reductions in leaf and twig CAG within protected shrubs at this site (Table 4), which may continue to increase as shrub competition intensifies in the absence of browsing.

\section{Beaked Hazel Browse Quality}

Overall, there were few significant impacts of removing herbivory on the quality of beaked hazel growth in 2000 . The lone significant effect $(\mathrm{P}<0.01)$ was an interaction between exclosure site and protection from herbivory on leaf crude protein $(\mathrm{CP})$, arising from a reduction $(\mathrm{P}<$ 0.05 ) in leaf $\mathrm{CP}$ at the Boreal and Shirley sites from 14.2 to $12.8 \%$, and 11.2 to $9.8 \%$, respectively, when protected from browsing. The decrease in leaf CP of protected beaked hazel shrubs within the Boreal exclosure coincided with an increase in leaf CAG (Table 4), thereby exemplifying the typical inverse relationship between forage quantity and quality (e.g., Van der Wal et al. 2000).

\section{Management Implications and Conclusion}

At the scale of individual beaked hazel stems, responses to the removal of her- bivory were evident at 3 of 4 sites over the 2 -year sampling period within shrubs protected from browsing. These results indicate current levels of herbivory within Elk Island National Park tend to be impacting some stands of beaked hazel by either reducing twig and leaf current annual growth, or altering their morphology. The documented changes in individual beaked hazel shrub growth after protection indicates that although this shrub is relatively tolerant of defoliation, particularly in comparison with more palatable species (Bork et al.1997b), current levels of herbivory continue to affect, and in some cases reduce, beaked hazel growth. In contrast, other than an increase in maximum shrub height, no plant community or beaked hazel population characteristic changed following protection. It is also notable that despite the positive responses observed at the individual shrub level, these changes failed to translate into greater browse production at the population level (data not shown). Thus, factors other than shrub competition may be preventing individual stem responses from translating into increased browse production, at least within the 2-year period examined here. Further vegetation changes are also likely following the removal of herbivores and their associated action on ecosystem processes, as several studies indicate browsing affects soil chemistry and nutrient cycling (e.g., Kielland and Bryant 1998, Ruess et al. 1998).

In summary, the results of this research support the notion that the overall effect of intensive ungulate browsing in Elk Island is to reduce individual beaked hazel stem growth and production. The variable nature of the responses among sites indicates factors such as precipitation, microclimate, plant species composition and resulting competition, overstory characteristics, and previous disturbance may also regulate beaked hazel growth. Our results for beaked hazel also parallel the findings of Wambolt et al. (1998) for bitterbrush (Purshia tridentata Pursh) on the importance of scale (e.g., shrub stem vs population) in quantifying and interpreting the impact of defoliation, as several individual beaked hazel stem responses were observed in this study despite minimal changes within the plant community. In conclusion, year-long browsing by native ungulates has reduced the number and aggregate twig length, as well as leaf and twig biomass, of beaked hazel current annual growth at several sites throughout the Park. However, these changes also appear reversible with the cessation of browsing. 


\section{Literature Cited}

Best, J.N. 2001. Assessing rangeland resilience to herbivory in Elk Island National Park. M.Sc. thesis. Dept of Agr., Food, and Nutr. Sci., Unive. of Alberta, Edmonton, Alberta, Canada 154 pp.

Blyth, C.B., N.L. Cool, A. Dickinson, R. Kaye, W.E. Olson, T. Osko, D.S. Madsen, and B. McDougall. 1994. Ecosystem status and management recommendations-Elk Island National Park. Heritage Resource Conservation, Elk Island National Park, Alberta, Canada. 95 pp.

Bonham, C.D. 1989. Measurements for terrestrial vegetation. John Wiley \& Sons Inc., New York, N.Y.

Bork, E.W., R.J. Hudson, and A.W. Bailey. 1997a. Upland plant community classification in Elk Island National Park, Alberta, Canada, using disturbance history and physical site factors. Plant Ecol. 130:171-190.

Bork, E.W., R.J. Hudson, and A.W. Bailey. 1997b. Populus forest characterization in Elk Island National Park relative to herbivory, prescribed fire and topography. Can. J. Bot. 75:1518-1526.

Bork, E.W., T. Thomas, and B. McDougall. 2001. Herbage response to precipitation in central Alberta boreal grasslands. J. Range Manage. 51:243-248.

Briske, D.D. and J.H. Richards. 1995. Plant responses to defoliation: a physiologic, morphologic and demographic evaluation. pp. 635-710, In: D.J. Bedunah and R.E. Sosebee (eds) Wildland Plants: Physiological Ecology and Developmental Morphology, Soc. for Range Manage., Denver, Colo.

Bryant, J.P., K. Danell, F. Provenza, P.B. Reichardt, T.A. Clausen, and R.A. Werner. 1991 Effects of mammal browsing on the chemistry of deciduous woody plants. pp 135-154, In: Tallamy, D.W., and M.J. Raupp (eds) Phytochemical induction by herbivores. John Wiley and Sons, New York.

Buckman, R.E. 1964. Effects of prescribed burning on hazel in Minnesota. Ecol. 45(3):626-629.

Crown, P.H. 1977. Soil survey of Elk Island National Park. Alberta Institute of Pedology Pub. No. S-77-38. 128 pp.

Danell, K., R. Bergström, and L. Ledenius. 1994. Effects of large mammalian browsers on architecture, biomass, and nutrients of woody plants. J. Mammal., 75:833-844.

Daubenmire, R.F. 1959. A canopy-coverage method of vegetational analysis. Northwest Sci., 33:43-64.

Environment Canada. 1993. Canadian climate normals: 1961-1990. Canadian Climate Program, Atmospheric Environment Service, Minister of Supply and Services Canada.

Hardy Associates Ltd. 1986. Ecological land classification of Elk Island National Park, Resource Conserv., Canadian Parks Serv., Elk Island National Park.
Hurlburt, S.H. 1984. Pseudoreplication and the design of ecological field experiments. Ecol. Monogr. 54:187-211.

Kielland, K. and J.P. Bryant. 1998. Moose herbivory in taiga: effects on biogeochemistry and vegetation dynamics in primary succession. Oikos, 82:377-383.

Kurmis, V. and E. Sucoff. 1989. Population density and height distribution of Corylus cornuta in undisturbed forests of Minnesota: 1965-1984. Can. J. Bot. 67:2409-2413.

Lauer, D.K. and G.R. Glover. 1999. Stand level pine response to occupancy of woody shrub and herbaceous vegetation. Can. J. For. Res. 29: 979-984.

LECO Corporation. Nitrogen Determinator, Model FP-428. LECO Corporation, St. Joseph, Mich., USA.

McKeague, J.A., Ed. 1978. Manual of soil sampling and methods of analysis. $2^{\text {nd }}$ Ed. Subcommittee on Methods of Analysis, Canada Soil Survey Committee, Canadian Soc. of Soil Sci. 212 pp.

Parks Canada. 1999. Elk Island National Park - ungulate issue analysis. Elk Island National Park, Fort Saskatchewan, Alberta, Canada 22 pp.

Ruess, R.P., R.L. Hendrick, and J.P. Bryant. 1998. Regulation of fine root dynamics by mammalian browsers in early successional Alaskan taiga forests. Ecol. 79: 2706-2720.

SAS Institute Inc. 1991. SAS system for linear models. $3^{\text {rd }}$ ed. SAS Institute Inc., Cary, N.C.

Steel, R.G.D., J.H. Torrie, and D.A. Dickey. 1997. Principles and procedures of statistics: a biometrical approach. $3^{\text {rd }} \mathrm{Ed}$. WBC/McGrawHill Co. Inc., New York, N.Y.

Tappeiner II, J.C. 1971. Invasion and development of beaked hazel in red pine stands in northern Minnesota. Ecol. 52(3):514-519.

Tappeiner II, J.C. 1979. Effect of fire and 2,4$D$ on the early stages of beaked hazel (Corylus cornuta) understories. Weed Sci., 27(2):162-166.

Tappeiner II, J.C. and H.H. John. 1973. Biomass and nutrient content of hazel undergrowth. Ecol. 54(6):1342-1348.

Tolvanen, A., K. Laine, T. Pakonen, E Saari, and P. Havas. 1992. Compensatory responses of a deciduous dwarf shrub, the bilberry (Vaccinium myrtillus L.) to stimulated herbivory: some comparisons with the evergreen lingonberry (Vaccinium vitis idaea $\mathrm{L}$ ). Acta Oecologica. 13:607-615.

Van der Wal, R., N. Nadan, S. van Lieshout, C. Dormann, R. Langvatn, and S.D. Albon. 2000. Trading forage quality for quantity? Plant phenology and patch choice by Svalbard reindeer. Oecologia. 123:108-115.

Wambolt, C.L. and H.W. Sherwood. 1999. Sagebrush response to ungulate browsing in Yellowstone. J. Range Manage..52(4):363-369.

Wambolt, C.L., W.W. Wyatt, and M.R. Frisina. 1998. Bitterbrush (Purshia tridentata Pursh) growth in relation to browsing. Great Basin Nat. 58:28-37.
Willoughby, M.G. 2000. Guide to range plant community types and carrying capacity for the dry and central mixedwood subregions of Alberta. Alberta Environ., and Alberta Agr., Food and Rural Dev. Pub. No. T/526.

Yokoyama, S. and E. Shibata. 1998. The effects of sika-deer browsing on the biomass and morphology of a dwarf bamboo, Sasa nipponica, in Mt. Ohdaigahara, central Japan. For. Ecol. Manage., 103:49-56. 